$$
\begin{aligned}
& p<i 0.5 \text { 又は } \frac{C x-C_{0}}{C g-C_{0}}<0.5 \text { ならば } \frac{C x-C_{0}}{C g-C_{0}}=\frac{4}{\pi \frac{3}{2}} \sqrt{p} \\
& \text { ">0.5 又は } ">\| \text { ならは }=1-\frac{8}{\pi^{2}} e^{-p}
\end{aligned}
$$

最後に畨流と混流との臨界流速につき論じ,レーノルッ゙数が 炏式の如くなり，面の傾斜に無開係なるべきを 推論せり。

$$
\frac{d \bar{u} \rho}{\mu}=\frac{4 V \rho}{a \mu}
$$

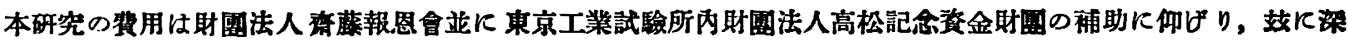
謝す。

·(東北帝國大學工學部化學工學研究室)（昭和 8 年12月 21 日受理）

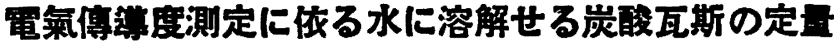

\section{八田四郎次・楫取 松若}

著者等は液體に依る瓦斯の吸收速度の研究に際して，水に溶解せる炭酸瓦斯を定量するの必要に遇遇して此

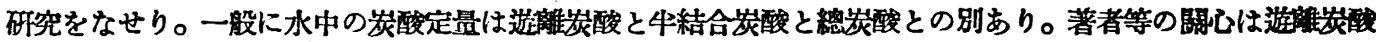
にあり。之は普通フェノールフタレインを指示薬とし苛性アルカリもて滴定せらる〉す正確なる值を得ず。若し 試料が炭酸㮾も重炭酸も含まざる場合には遊離灰酸と總发酸とは同一なるを以て，試料に $\mathrm{Ba}(\mathrm{OH})_{2}$ 液を加へ

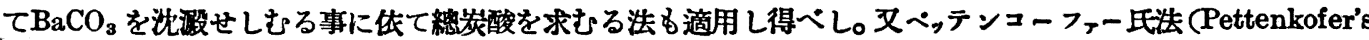
method; Lunge and Keane: Technical Methods of Chemical Analysis, 2nd Ed., Vol. III, p. 456) 郎 ち試料に過量の $\mathrm{Ba}(\mathrm{OH})_{2}$ 液を加へて $\mathrm{CO}_{2}$ を全部 $\mathrm{BaCO}_{3}$ として沈没せしめ, 静置後上澄液を酸もて逆滴定 するの沠る適用するを得へし。されど之等の方泆は手數と時間とを要する事多く，且つ操作中に $\mathrm{Ba}(\mathrm{OH})_{2}$ が 空氣中の $\mathrm{CO}_{2}$ を吸收する事に化る誤差の恐れあり。依て著者等は夷の如き方法を研究せり。郎ち一定容の訊 料水と一定容の $\mathrm{Ba}(\mathrm{OH})_{2}$ 液を混和して $\mathrm{CO}_{2}$ を全部 $\mathrm{BaCO}_{3}$ として沈渐せしめ牫留せる $\mathrm{Ba}(\mathrm{OH})_{2}$ を電氣 傳導度測定に化て求め, 別に未だ $\mathrm{CO}_{2}$ を吸收せざる前の試料又は煮沸して $\mathrm{CO}_{2}$ を追出したる試料につき同

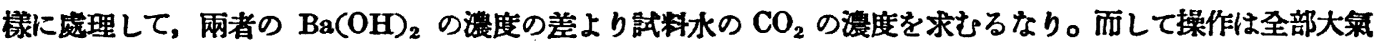

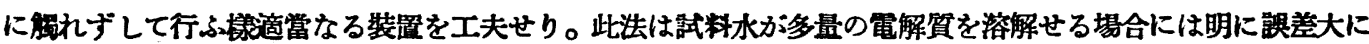
て適用し得ず。されど電解貿が微量ならば誤差も大ならず。著者等の破究は主として純水に $\mathrm{CO}_{2}$ を溶かせる

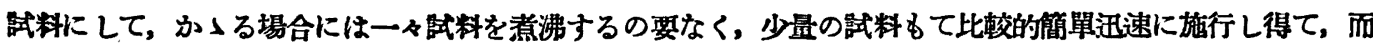
も結果は充分に正確なり。上下先づ純水中の $\mathrm{CO}_{2}$ の測定につき述べ，然る後電解質の影脾に言及すへし。

\section{測 定 用 裝 置}

水酸化バリウム液は空氣に觸るれば容易に炭酸瓦斯を㩖收して誤差を生ずるを以て之を避くるため第 1 圖の 裝置を用ひたり。中央の $\mathrm{A}$ が傳通度測定槽にて，左右の $\mathrm{B}$ 及 $\mathrm{C}$ は夫ょ $\mathrm{Ba}(\mathrm{OH})_{2}$ 液及試料水を量り探るヒ ベゥトなり。C の上には略 B と同大の D あり。 A, B 及 C は圖の如く 4 個の三卌活栓もて連結せり。 $\mathrm{E} の$ 端は $\mathrm{Ba}(\mathrm{OH})_{2}$ 液容器に浸され，F の端より試料水並に洗湅水を吸入す， G は液の排泄口なり。 $\mathrm{A}, \mathrm{B}$ 及 $\mathrm{C}$ の上には夫々 $\mathrm{H}, \mathrm{J}$ 及 $\mathrm{K}$ の曹達石灰管を附したり。

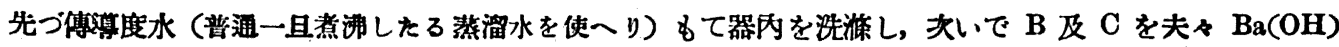


第 1 圈 测定裝置

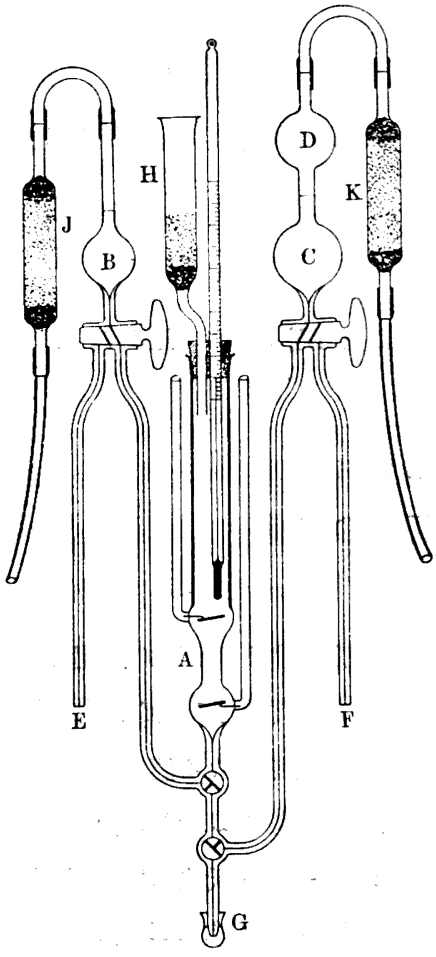

液及試料水るて洗ひたる後， $\mathrm{B} に \mathrm{Ba}(\mathrm{OH})_{2}$ 液， $\mathrm{C}$ に試料水を探り， 4 個の活栓を邂當に働かせて雨液を $\mathrm{A}$ に湀る。然る後液の均一なる混 合を助くる䉆 $\mathrm{A}$ と CD 間を 1〜2 度往復せしめ, 更に J 又は $\mathrm{K}$ の

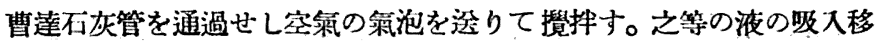
動並に空氣の湀入は凡て曹達不灰管の端に附せしゴム管のつまみ湀り に依れり。此装置もて室溫にて傅導度を測定し同時に液の溫度を讀む なり。

裝遗の檢度

試料が電解質其他の溶質を含まざる時は，傳導度測定液は $\mathrm{BaCO}_{3}$ の沘澱を含有する外純粹なる $\mathrm{Ba}(\mathrm{OH})_{2}$ 液なるべきなり。此の故に先 つ $\mathrm{Ba}(\mathrm{OH})_{2}$ の湄度と傅導度との關係を求むべし。郎ち $\mathrm{B}$ には滴定 に依る既知濃度の $\mathrm{Ba}(\mathrm{OH})_{2}$ 液, $\mathrm{C}$ に傳導度水を探りて傳導度を測定 すべし。元來傅導度は濃度の外溫度の函數なれば一定溫度にて测定す るが最も望ましけれども著者等は簡單迅速に求もる篇空溫にて测定し 從て溫度の補正をなす事とせり。此の故に先つ傳荨度の溫度倸數を求 もるの必要まり，郎ち傳導度槽をヂュワー堔水槽に保ちて凡そ 10〜34 ${ }^{\circ} \mathrm{C}$ の範圈に於て $(d \lambda / d t)\left(1 / \lambda_{13}{ }^{\circ}\right)$ を求めて 0.0176 及 $0.0054 \mathrm{~mol}$ の 兩液に付き夫々 0.0190 及 0.0196 を得たり。交献 (Landolt's Tabellen, 5. Aufl., S. 1078）に依れば 0.15 及 $0.074 \mathrm{~mol}$ に付き夫々 0.0185

及 0.0187 なり。之に依れば溫度係數は濃度の增加と共に僅に減少するの傾あり。されど著者等は测定の範㗄

第 2 圖 抵抗一罣度- $\mathrm{Ba}(\mathrm{OH})_{2}$ の潘度

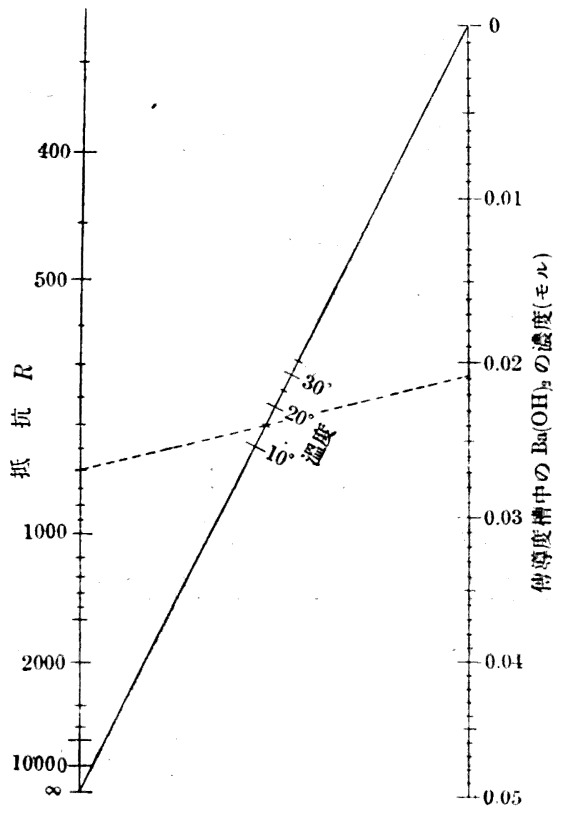

內に於て濃度に無關係 と見做して䖪測の平均值 0.0193 を探机 り。郎ち

$$
\lambda=\lambda_{10}{ }^{\circ}\{1+0.0193(t-18)\}
$$

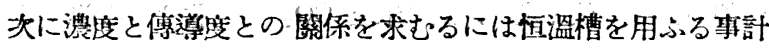
算上便利とすべきる，著者等は室溫にて测定し（1）式もて 18 ${ }^{\circ} \mathrm{C}$ の佂を計算せり。空際測定の 溫度は $18.9 \sim 20.2^{\circ} \mathrm{C}$ なればこ の方法もて立分の正傕度を得るを信じたればなり。實簽の結果 は電導度槽中の $\mathrm{Ba}(\mathrm{OH})_{2}$ 液の濃度を $C \mathrm{~mol} / l$ とせば, $\left(\lambda_{18}{ }^{\circ} / C\right)$ 對 $C$ が直楾となり, 郎ち

$$
\lambda_{18}{ }^{\circ}=f(C)=a C-b C^{2}
$$

もて表はし得るを認め、平均法によりて次式を得たり。

$$
\lambda_{18}{ }^{\circ}=f^{\prime}(C)=0.06764 C-0.1923 C^{2}
$$

但し $\lambda$ は比傳導度に非ずして直接測定したる抵抗 $R$ の逆數 なり。以上の結果より次式を得らる。

$$
\lambda=\frac{1}{R}\left(0.66764 C-0.1923 C^{2}\right)\{1+0.0193(t-18)\}
$$

之郎ち $\mathrm{Ba}(\mathrm{OH})_{2}$ の濃度 $C$, 溫度 $t$, 及㑑導度又は抵抗との 
關係式なり。但し $C$ の湘定範囯は $0.0027 \sim 0.0476$ にして $C$ が著しく大又は小とならは適用されず，(4) 式 は第 2 圆の如きノモグラフに表はして一«の計算の煩を避けたり。算㡜使用のるのは $\lambda$ 及 $f(C)$ の尺度單位

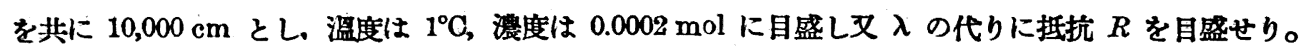

第 1 表 計算濃度と蛪測濃度との比較 溫 度 $\left({ }^{\circ} \mathrm{C}\right)$ 抵抗 $(\Omega)$ 計算搌度 $(\mathrm{mol})$ 宣测源度 $(\mathrm{mol})$

\begin{tabular}{|c|c|c|c|}
\hline 11.8 & 3160 & $0.0053_{o}$ & $0.0053_{3}$ \\
\hline 21.5 & 2530 & $0.0053_{5}$ & \\
\hline 33.0 & 2110 & $0.0053_{s}$ & " \\
\hline 10.4 & 516 & $0.0375_{0}$ & $0.0376_{o}$ \\
\hline 25.0 & 389.5 & " & " \\
\hline 20.0 & 5130 & $0.0272_{5}$ & $0.0376_{\sigma}$ \\
\hline 19.7 & 1375 & $0.0107_{s}$ & $0.0107^{6}$ \\
\hline " & 714 & $0.0216_{5}$ & $0.0215_{\sigma}$ \\
\hline " & 433 & $0.0375_{o}$ & $0.0376_{o}$ \\
\hline 19.8 & 345 & $0.0481_{0}$ & $0.0476_{0}$ \\
\hline
\end{tabular}

斯くて (4) 式を得るまでの虹驗結果とノモグラフ の讀とを比㣀し其數例を第 1 表に示せり。之に依れ

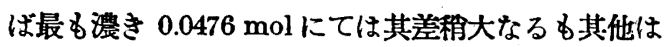
ほ心゙涩足なるを見るべし。

以上の結果を用ひて純水中に溶けたる $\mathrm{CO}_{2}$ の濃度 を求むるには头の如くすべし。先づ標準の $\mathrm{Ba}(\mathrm{OH})_{2}$ 液を $\mathrm{B}$ に, $\mathrm{CO}_{2}$ を含まざる蒸溜水を $\mathrm{C} に$ 探りて上 の法に依りて $\mathrm{Ba}(\mathrm{OH})_{2}$ の㳪度 $C_{\mathrm{o}}$ を求む。头に此 の $\mathrm{Ba}(\mathrm{OH})_{2}$ 液と試料水とより同樣にすれば $C_{\mathrm{o}}$ よ

り小なる $C_{1}$ を得へし。え $\mathrm{CO}_{2}$ の篇に等量の $\mathrm{Ba}(\mathrm{OH})_{2}$ が $\mathrm{BaCO}_{3}$ として沈澱したればなり。然らば試料 中の $\mathrm{CO}_{2}$ の濃度 $x \mathrm{~mol} / l$ は次式より得らる。

$$
x=\left(C_{0}-C_{1}\right)\left(\frac{V_{1}+V_{2}}{V_{2}}\right)
$$

但し $V_{1}$ 及 $\dot{V}_{2}$ は夫々 $\mathrm{Ba}(\mathrm{OH})_{2}$ 液及試料水ピベっトの容䡠なり。序にピベ,トに探りし $\mathrm{Ba}(\mathrm{OH})_{2}$ の原液 の濃度 $a$ と $C_{0}$ との間に次の關係ある事は言を俟たず。

$$
C_{0}=a\left(\frac{V_{1}}{V_{1}+V_{2}}\right)
$$

然るに聯に珼か注意すべき事は, 液中にある $\mathrm{BaCO}_{3}$ の沈激か傳導度測定に影響なきやの問題なり。著者等 は之を检する篇, 或濃度の $\mathrm{Ba}(\mathrm{OH})_{2}$ の液を探り, えに $\mathrm{CO}_{2}$ を通じて一部を $\mathrm{BaCO}_{3}$ として沈澱せしめたる 後，(a）全體を好く均一に雤汼したる液，(b) 液を静置して得たる上澄液，(c) 静置して底部に多量の $\mathrm{BaCO}_{3}$ と共存する液の 3 者を上の傳導度槽に探りて湘定し $20.0^{\circ} \mathrm{C}$ に於て夫々 821,822 及 $823 \Omega$ を得たり。郎ち沈

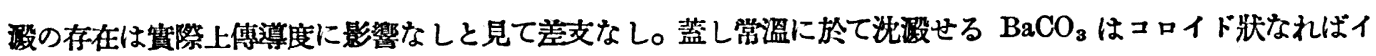
オンの如きは自由にその間を通過するが爲なるべし。されと沈澱が著しく多昷ならば恐らくは影響なきに非ざ るべきを以てかいる事を避ける篇に $V_{1}$ と $V_{2}$ との比を適當に選定するの要あるべし。

著者等の裝置は $V_{1}=5.00 \mathrm{cc}, V_{2}=15.00 \mathrm{cc} に し て, 之 に$ 依りて少量の試料を以て比較的迅速に水に溶解せる $\mathrm{CO}_{2}$ を測定するを得たり。例へば先つ $\mathrm{CO}_{2}$ を含まざる蒸溜水を用ひて $t=16.9^{\circ} \mathrm{C}, R=542 \Omega$ より $C_{0}=0.03040$ $\mathrm{mol}$ を得, 次に試料水を用ひて $t=17.0^{\circ} \mathrm{C}, R=908 \Omega$ より $C_{1}=0.01740 \mathrm{~mol}$ を得, (5) 式より $x=0.0173$ を 得。換言すれば水 $1 \mathrm{cc}$ につき $\mathrm{CO}_{2} 22.26 \times 0.0173=0.355 \mathrm{cc}$ (標潐狀態)を溶かせるなり。

氣中の $\mathrm{CO}_{2}$ を定量するに $\mathrm{Ba}(\mathrm{OH})_{2}$ 液の傳導度を湘定するの方法は Caia 及 Maxwell 兩氏 (Ind. Eng. Chem., 1919, 11, 852）に依りて呆出せられ，其後の研究もありて鐵鎙中の炭素分析, 生物の呼吸作用の研究等

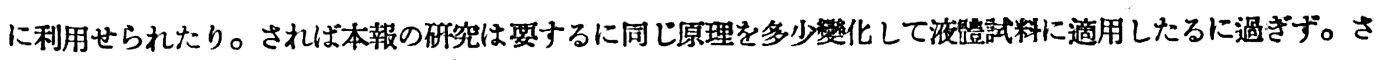
れど電氣抵抗，溫度及港度間の閵係式及其のノモグラフは著者等のるのが合理的にして正確なるを信ず。 
試料中に溶解せる電解質の影響

著者等の研究は主として純水に溶解せる $\mathrm{CO}_{2}$ の測定に存したれども，一般の場合としては試料水に溶解せ る電解質其他の溶質の影響を究めざるべからず。䢧般の影響は溶質の種類、濃度、溫度等に依りて異なり，之 を豲密に考察すれば決して簡單なるものに非ず。されど電解質の量が大ならざる場合には次の法に依り誤差の 著しく大なら゙ざる結果を得へし。郎ち先つ試料水と $\mathrm{Ba}(\mathrm{OH})_{2}$ とより上述と同樣にして傳導度を測定して見掛 の濃度 $C_{1}{ }^{\prime}$ を求め, 次に $\mathrm{CO}_{2}$ を未だ吸收せざる試料又は試料を煮沸して $\mathrm{CO}_{2}$ を追出したる液（逆流冷綰器 を附して溶質の濃度の變化を防止すべし)を用ひて同樣にして見潮の濃度 $C_{0}{ }^{\prime}$ を求む。而して此の $C_{1}{ }^{\prime}$ 及 $C_{0}{ }^{\prime}$ を 夫々 $C_{1}$ 及 $C_{0}$ と見做し (5) 式に依りて $\mathrm{CO}_{2}$ の濃度 $x$ を計算するなり。此場合には傳導度を測定したる液

第 3 圖 電解質の影䂑の一例

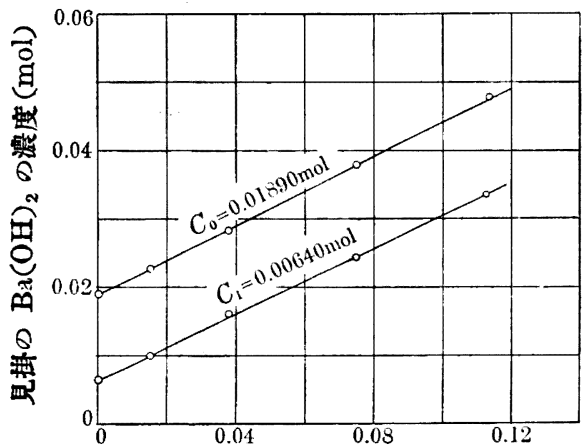

傳導度测定液山の $\mathrm{NaCl}$ の濃度 $(N)$ は $\mathrm{Ba}(\mathrm{OH})_{2}$ と試料中の電解質との混合液なるを以て, $C_{\mathbf{x}}{ }^{\prime}$ 及 $C_{\mathrm{o}}{ }^{\prime}$ は商の $\mathrm{Ba}(\mathrm{OH})_{2}$ の濃度に非ず, されど傳導度の差 は $\mathrm{BaCO}_{3}$ の沈澱による $\mathrm{Ba}(\mathrm{OH})_{2}$ の濃度の減少にのみ䟮因 す。依て嚴格に見れば種々導入の原因あるも，電解質の濃度 大ならざる時は大略 $C_{0}{ }^{\prime}-C_{1}{ }^{\prime}=C_{0}-C_{1}$ と見做すを得へし。 之を實驗に徽せんが瓷，一例として $\mathrm{NaCl}$ 液を探れり。而し， て濃度の異なる $\mathrm{Ba}(\mathrm{OH})_{2}$ の 2 液を探り，先づ純水を用ひ て傳望度を測定して $C_{0}$ 及 $C_{1}$ を求め, 其差か水中の $\mathrm{CO}_{2}$ に 歸因すと見做して $x$ を計算せり。次に此の $\mathrm{Ba}(\mathrm{OH})_{2}$ の 2 液 と諸種の濃度の $\mathrm{NaCl}$ 液とを用ひて夫々見掛の濃度 $C_{0^{\prime}}{ }^{\prime}$ 及 $C_{1}{ }^{\prime}$ を求め之より $x$ を計算して純水の場合と比较せり。但し實驗は夫々唯 1 四のみにて稍々不正確なれば第

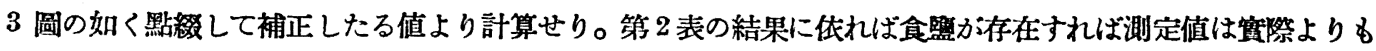
過大なるの傾向あり。然れども本宸驗の條件にては $\mathrm{NaCl}$ が $0.05 \mathrm{~N}$ の試料にて誤差 $3 \%, 0.02 \mathrm{~N}$ にて 1\%な れは普通の河水鑛泉の如きもの」遊離炭酸の測定には適用し得ざるに非ざるべし。要するに此場合の正確度は 槽中の $\mathrm{Ba}(\mathrm{OH})_{2}$ と他の愈との濃度の割合に毷る事大にして, 之は $\mathrm{Ba}(\mathrm{OH})_{2}$ と試料との比を加減すれば或 程度まで調節し得べし。

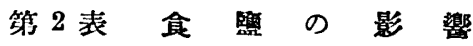

\begin{tabular}{|c|c|c|c|c|c|}
\hline 試料中の $\mathrm{NaCl}$ の㴚度 $(N)$ & 0 (粁水) & 0.02 & 0.05 & 0.10 & 0.15 \\
\hline 傳導度槽內の $\mathrm{NaCl}$ の浱度 $(N)$ & 0 & 0.015 & 0.0375 & 0.075 & 0.1125 \\
\hline$C_{\mathbf{0}}^{\prime}\left\{\begin{array}{l}\text { 實測值 } \\
\text { 補正值 }\end{array}\right.$ & $\begin{array}{l}0.0189 \text { o } \\
\text { // }\end{array}$ & $\begin{array}{l}0.0226_{0} \\
\text { "I }\end{array}$ & $\begin{array}{c}0.0282_{\text {s }} \\
\text { / }\end{array}$ & $\begin{array}{c}0.0378_{6} \\
\prime \prime\end{array}$ & $\begin{array}{l}0.0477_{\sigma} \\
0.0473_{\text {s }}\end{array}$ \\
\hline$C_{1}^{\prime}\left\{\begin{array}{l}\text { 䗙䝵值 } \\
\text { 正值 }\end{array}\right.$ & $\begin{array}{c}0.0064_{0} \\
\|\end{array}$ & $\begin{array}{c}0.0100_{0} \\
/ 1\end{array}$ & $\begin{array}{l}0.0151_{0} \\
0.0153_{5}\end{array}$ & $\begin{array}{c}0.0243_{5} \\
\prime \prime\end{array}$ & $\begin{array}{c}0.0335 \text { o } \\
\quad 1\end{array}$ \\
\hline$C_{\mathrm{o}}^{\prime}-C_{\mathrm{1}}^{\prime}$ & $0.0125_{0}$ & $0.0126_{0}$ & $0.0129_{0}$ & $0.0135_{0}$ & $0.0138_{s}$ \\
\hline 誤 ${ }^{x}$ & $\begin{array}{c}0.0166_{7} \\
-\end{array}$ & $\begin{array}{c}0.0168 \text { o } \\
1 \%\end{array}$ & $\begin{array}{c}0.0172_{o} \\
3 \%\end{array}$ & $\begin{array}{c}0.0180_{o} \\
8 \%\end{array}$ & $\begin{array}{l}0.0184_{7} \\
11 \%\end{array}$ \\
\hline
\end{tabular}

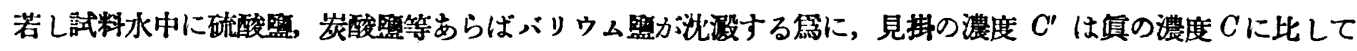
著しく埥加せず，從て結局比較的正確なる值を得べし。又重炭酸アルカリは煮沸に依りて牛分の $\mathrm{CO}_{2}$ を失ふ， 故、之を含む試料にては选雍炭酸と斗結合炭酸との和を得らるななり。

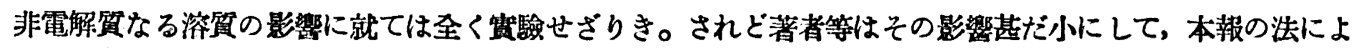


りて充分に滿足なる値を得べきを思ふなり。

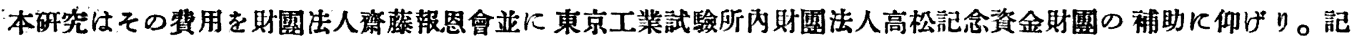
して茹に謝意を表す。

（東北帝國大學工學部化學工學研究室）（昭和 8 年 12 月 21 日受理）

\title{
薄層狀に流るる水に依る炭酸瓦斯の吸收速度の研究
}

\begin{abstract}
八田四郎次・楫取 松若

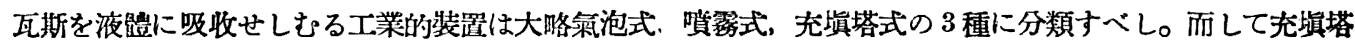
式は單位容積內の接觸面積の大なると瓦斯の压力低下の比較的小なるとの長所に依り楆めて鹿く使用せらる。 されど之が研究は未だ甚だ足らず，著者等は從來一般の考察の意に滿たざるものあり，之が基礎的䃑究をなさ んとす。本報は其一部なり。元來充泻荅にては瓦斯を塔つ下部より, 液を塔の上部より供給して, 兩者の向流 する間に吸收が起るものなろが，此際液は荅內の充泻物の表面に添ひて薄曆爿をなして流下し，瓦斯は充填物

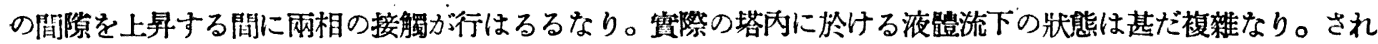

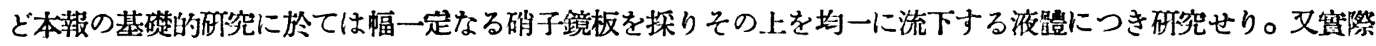
の塔にては氯相內の被吸收成分は塔底に於て最も富み上昇するにつれて減少するも，著者等は純粹に近き瓦斯

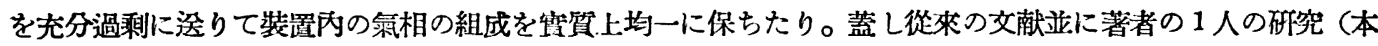
誌，昭和 3,31，869；昭和 7,35, 1397；昭和 8,36,7）に依れば溶解度の特に大なる瓦斯を除き，多くの 場合には吸收の抵抗は主として液側にあり，故に研究は先づ夜側の現象を明にすへくく此鿺には氣相を均一組成 に保つの便利なるを䀔めたるなり。
\end{abstract}

Haslam, Hershey 及 Keen 氏等 (Ind. Eng. Chem., 1924, 16, 1224) は中空の直立圓筒の内壁に添ひて 流下せしめたる液につき諾種の瓦斯を吸收せしめて L9wis 氏等の二重膜說 (Lewis and Whitman, Ind. Eng. Chem., 1924, 16, 1215) の穻當なる事を證せり。されど氏等は圓筒の高さ及液の流速の 影響を政究せざ りき。本報にては液の流下面の長さ及液の流速の影響を硼究し, 又面の傾科の影響も踏せり。其結果液の流 速が小となれば二重膜則が適用し得ざる事を認め，此場合には液が曆流 (Stream-line flow)をなすと見做し て誘導せる吸收の理論式と苴測とが凡そ一致する事を認めたり。研究仏料としては水に依る炭酸瓦斯の四收を 探れり。適度の溶解度, 取扱の便易等道般の研究に最も適當なるを認めたればなり。

\section{實驗裝置}

第 1 圆の A か 硝子鏡板にて長さ $36 \mathrm{~cm}$, 幅 $3 \mathrm{~cm}$ あり。中央幅 $1.5 \mathrm{~cm}$ を液の流下面とす。依て此幅の左右

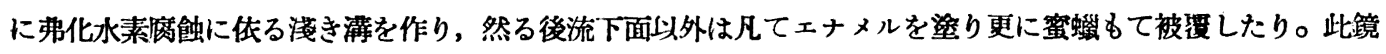
板をば水套を有する圆筒內に入れ，圖の吝くパラフィン屏によりて鏡板の位置を固定す。液は B より一定の流 速にて入り，C の狹き間陌より鏡板上に邆らる。C を製するには硝子管に薄き銅板を入れ，成形の後硝酸に

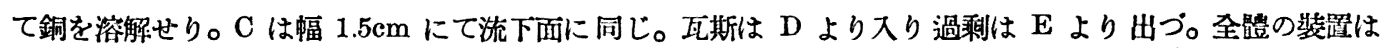

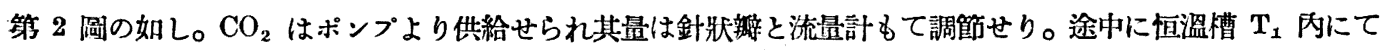

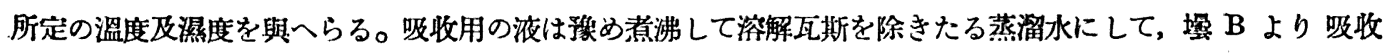

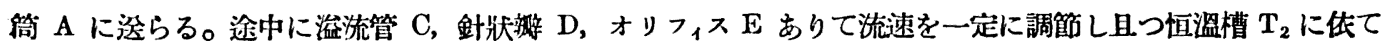

